\title{
Correlation of Anthropometric Indicators to Vital Capacity of Young Sportsmen
}

\author{
Ikonomi E. ${ }^{1}$, Daulle E. ${ }^{2}$, Çerra E. ${ }^{3}$, Canaj F. ${ }^{4}$ \\ ${ }^{1}$ Sport University, Tirana, Muhamet Gjollesha Road,Tirana, Albania \\ ${ }^{2}$ Abi Bank, 7,Elbasan Road,Tirana,14/1,Albania \\ ${ }^{3}$ Environment Ministry, 42,Artan Lenja Road,7,Tirana, Albania \\ ${ }^{4}$ Sport University, Tirana, Muhamet Gjollesha Road,Tirana, Albania
}

\begin{abstract}
In assessing health situation of young sportsmen is an important indicator of bodily development. This development is related to a series conditions internal (genetic) and external, such as food, physical activity, etc. The impact of these factors, the pace of development anthropometric of physiological, often based on objective assessments. Subjects that were measured in the study were: 93 young male sportsmen the sports club "Tomori" and 56 young female sportswoman sports club "Partizani". Statistical data processing was done on computers, by deriving, arithmetic average $(X)$, which is calculated by the method ANOVA, standard deviation (SD) and linear regression is calculated by method EXEL 2010. Anthropometric measurements, thoracic perimeter, spirometry, vital capacity comprise results of the study in both sexes studied. Components reserve of function breath exchanger for men were: volleyball 5.8; 2.6, combat sports 4.4; 4.5, soccer 2.8; 3.7, gymnastics 6.0; 2.2 basketball 5.7; 2.5, females were: volleyball 4.5; 3.6, combat sports 3.6; 2.8 athletics 4.6; 4.1, gymnastics 4.3; 3.6 basketball 6.3; 3.3. Conclusion: High efficiency respiratory affects many energy savings by respiratory muscles, where $10 \%$ of the total energy spent consuming respiratory muscles, but when their productivity rise, the percentage of spending low.
\end{abstract}

Keywords: Young athletes, anthropometric parameters, breath exchanger.

\section{Introduction}

Breath exchanger understand all the processes that take part in the transfer of oxygen from the atmosphere to tissue cells (respiration) and vice versa (expiration) [1]. Breath exchanger is: external and internal. With breath exchanger external mean oxygen uptake from the atmosphere in the alveoli, his connection with $\mathrm{Hb}$ (hemoglobin), his plasma digestion and extraction of carbon dioxide (CO2) from cells in the alveoli and the atmosphere intraeritrocitare and exstraeritrocitare forms. Utilization of oxygen by cells extraction of carbon dioxide (CO2) from makeup internal breath exchanger [2]. The lungs consist of alveoli, in which an exchange of gases between air and blood, found in the lung capillaries and of the conveying system, consisting of the trachea, bronchi, bronchioles etc. Air arrives in alveoli during respiratory during expiration leave them. Since as transport system is not participating in gas exchange, it said that it makes breath exchanger dead space. Alveoli constitute about $95 \%$ of the volume of the lungs. Each alveolus is wrapped by a mesh pulmonary capillaries. Thus, the total area of contact between the alveolar air and blood in the capillaries present is quite wide, enabling a rapid exchange of gases [3]. Respiration driven by a discharge nerve impulses from the respiratory center, which is found in the bulb. These impulses are directed to the respiratory muscles, primarily the diaphragm and ribs external muscles. The contraction of these muscles expands breast because the lungs are practically adjacent to inside pages of the wall of the chest and the face of the upper diaphragm, which are permeated by layers of fluid intermediate, where the volume of their enlarged [1]-[4]. With the expansion of the lungs, the pressure inside sits under atmospheric pressure $(4-8 \mathrm{mmHg})$ of air is drawn inside, thus committing an act of breath suck [2]. Lungs are elastic structure and hence the trend continued to leave the chest wall, exercising what is called flexible withdrawals. As a result, the existing pressure of the fluid layer, which is between two parts of the pleura (pleura space, is a little lower than the atmospheric pressure) in each case about 2-3 mmHg. Breath suck expands the lungs and thus makes it possible to increase the strength of their withdrawal flexible, which makes the pleura pressure lower than atmospheric pressure, 3-4 $\mathrm{mmHg}$ [5]. When the breathing centers not on impulse discharges, the muscles breath suck issued the pull enlarged elastic lung and chest wall makes these structures again occupies a smaller volume, which corresponds to their state of rest. Consequently, the internal pressure of the lungs becomes higher than that of the atmosphere, $+1-\mathrm{H}+2 \mathrm{mmHg}$. Thus, the air out of lungs and this it expiration [6]. But under normal conditions of rest, breath suck is a phenomenon active, which depends on the contraction of muscles respiration while expiration is a phenomenon passive dependent increase in the withdrawal elastic lung and the wall of the chest, drawing the benefits of respiration previous [5]. With the start of exercise, it is the immediate increase of respiratory. When the case of the state stimulation, caused by competition, it may be a respiratory precocity, before it has started work [7]. For a workload to give, show two phases of the response of respiratory initial rise faster, which was discussed above, which is followed by a slow development, to the value of the last, held throughout the exercise [8]. Setting the initial phase is quite fast and happens before the metabolic product derived from the muscles that are contracted to have the opportunity to reach the respiratory center. We believe that it is caused by

Volume 5 Issue 7, July 2016 www.ijsr.net 


\section{International Journal of Science and Research (IJSR) \\ ISSN (Online): 2319-7064}

Index Copernicus Value (2013): 6.14 | Impact Factor (2015): 6.391

impulses that reach the respiratory center, coming from the cerebral cortex [9]. There is a considerable lack in achieving the final respirator maximum level, which makes the thought of an influential increasingly and greatest chemical reflex on the respiratory center. In the case of moderate exercise, usually reached a steady state within a period of time, lasting 3-5 minutes. That said more or less the same interval of time that is required to fully perform the circulatory adjustments. This fact forces us to acknowledge that some control factors are common to both types of regulation [10]. In the case of hard exercise, the volume and frequency respiratory and can continue to grow throughout the period of work even though it may displayed a slight decrease flow purpose [7]-[9]. Time needed to return to the level respiration exercise is determined by the difficulty, the duration of the exercise of the physical state of exercisers. This time, due to the shrinking fast training, responding more or less time needed to achieve maximum ventilation during the initial phase of the exercise [11]. After an exhausting exercise, breathing return to the level of exercise can be considerably retarded. Respiratory rate usually returns to slowly than the depth respiratory [12].

\section{Purpose of the study}

Examination of anthropometric parameters increase of vital lung capacity of young sportsmen, as well as the difference between the categories in different sports, depending on sex and age, in different kinds of sports.

\section{Methodology}

In this study, subjects were measured were 93 young male sportsmen the sports club "Tomori" and 56 young female sportswoman sports club "Partizani". Respective divisions by gender in various types of sports are presented in tables 1 and 2, as follows:

Table 1: Number male sportsmen by type of sports

\begin{tabular}{|c|c|}
\hline Male & Number of sportsmen \\
\hline Volleyball & 13 \\
\hline Combat sports & 21 \\
\hline Gymnastics & 9 \\
\hline Basketball & 20 \\
\hline Soccer & 30 \\
\hline
\end{tabular}

Table 2: Number female sportswomen by type of sports

\begin{tabular}{|c|c|}
\hline Female & Number of sportswomen \\
\hline Volleyball & 14 \\
\hline Combat sports & 8 \\
\hline Gymnastics & 8 \\
\hline Basketball & 11 \\
\hline Athletic & 15 \\
\hline
\end{tabular}

For our study used these devices:

- Weighing machine.

- Height-meter wood.

- Tape-meter.

- Spirometer letter combustion "EUTEST".

- Computer.

Measurements were realized the afternoon during March 2016, regular laboratory conditions, using environments sports clubs "Tomori" and "Partizani". Subjects in the study was dressed in sport suit. Temperature environments where developed measurements it was 260 degrees. These parameters were measured:

- Body weight $(\mathrm{kg})$.

- Body height (cm) [17].

- Perimeter the chest to respiration of tranquility $(\mathrm{cm})$.

- Perimeter thoracic respiration deep $(\mathrm{cm})$.

- Perimeter thoracic in deep expiration $(\mathrm{cm})[16]$.

- Spirometry and vital capacity (ml) [15].

On the basis of these data, calculated several indicators, which are presented below:

- Chest elasticity, which is difference between the perimeter of deep respiration by deep expiration [16].

- Difference between respiration perimeter of expiration perimeter with tranquility.

- Difference respiratory, tranquility and deep expiration [18].

- Spirometry with body height (spiroindeks 1) and body weight (spiroindeks 2) [15].

- Ideal vital capacity calculated based on energy needs that has a body with body weight, height and body dimensions.

This last, according to the equation that determines energy metabolism, gives us the possibility of calculating the Vital capacity ideal (VCI). The following are showing Harris \& Benedict equations [13]-[14] the method of calculation:

$$
\begin{aligned}
& \text { Male } \mathrm{BM}=66473+13,751 *(\mathrm{BW}) \\
& \quad+5.0033 *(\mathrm{BH})-6755 *(\mathrm{Age}) \\
& \text { Female } \mathrm{BM}=65.50955+9463 *(\mathrm{BW}) \\
& \quad+1.8496 *(\mathrm{BH})-4.6756 *(\mathrm{Age})
\end{aligned}
$$

BM-Basic Metabolism, BW-Body Weight, BH-Body Height. $\mathrm{VCI}=\mathrm{BM}^{*} 2.3$ male $\quad \mathrm{VCI}=\mathrm{BM}^{*} 2.1$ female

\subsection{Statistical methods}

Through statistical analysis method, the study showed progressive results as concrete material and argumentative. All data obtained from tests performed, were subjected statistical analysis. Statistical data processing was done on computers, by extracting:

- Arithmetic mean (X), which is calculated by the method according to ANOVA general equation:

$$
\text { AVERAGE }=\text { Data }
$$

- Avoidance quadratic average (standard deviation (SD) is calculated by the method EXEL 2010, with the general equation:

$$
\text { STDEV Excel }=\text { Data }
$$

- EXCEL 2010 linear regression.

Excel is used in package "Data Analysis" (DA) for the implementation of statistical analysis, which is Microsoft extra package, which was activated by the user when we needed statistical analysis.

\section{Volume 5 Issue 7, July 2016 www.ijsr.net}




\section{International Journal of Science and Research (IJSR) ISSN (Online): 2319-7064}

Index Copernicus Value (2013): 6.14 | Impact Factor (2015): 6.391

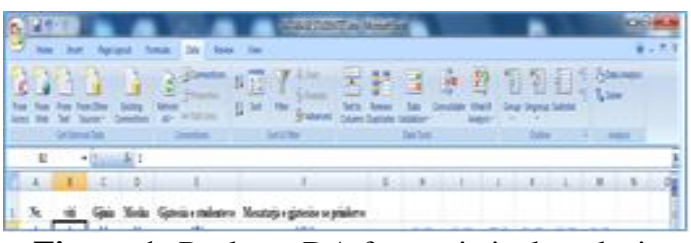

Figure 1: Package DA for statistical analysis

\section{Results}

\subsection{Male}

In table 3 , we present the data of sportsmen anthropometric measurements. While the height changes according to the type of sport, the same change look to bust and weight. [17]

Table 3: Data of sportsmen anthropometric measurements

\begin{tabular}{|c|c|c|c|c|c|}
\hline \multicolumn{2}{|c|}{ Sports disciplines } & Age & Height & Bust & Weight \\
\hline \multirow{2}{*}{ Volleyball } & Av. & 17.3 & 180.4 & 92.3 & 68.2 \\
\hline & SD & 0.9 & 5.4 & 3.1 & 6.8 \\
\hline \multirow{2}{*}{$\begin{array}{l}\text { Combat } \\
\text { sports }\end{array}$} & Av. & 17.9 & 171.3 & 89.7 & 76.8 \\
\hline & SD & \pm 3.7 & \pm 7.7 & \pm 4.2 & \pm 17.0 \\
\hline \multirow{2}{*}{ Gymnastic } & Av. & 16.7 & 162 & 82.3 & 58.8 \\
\hline & SD & \pm 1.8 & \pm 8.1 & \pm 4.2 & \pm 21.8 \\
\hline \multirow{2}{*}{ Basketball } & Av. & 17.8 & 182.2 & 92 & 76.2 \\
\hline & SD & \pm 1.1 & \pm 5.2 & \pm 19 & \pm 6.7 \\
\hline \multirow{2}{*}{ Soccer } & Av. & 18 & 173.2 & 91.7 & 70.8 \\
\hline & SD & \pm 1.4 & \pm 5.1 & \pm 3.5 & \pm 10.8 \\
\hline
\end{tabular}

In table 4 , we present the measurement data of the chest perimeter. From the data, we see that the largest perimeter have combat sports, such as respiratory and elasticity. [16] In table 5, we present two ingredients breath exchanger reserve function, which are the difference between the perimeters of deep respiration and tranquility and deep peace and expiration. From the table, and we distinguish that respiration is the main component of the act breath exchanger, looking at that besides soccer, this ingredient in other sports is almost twice higher than expiration deeply [18].

Table 4: Male chest perimeter measurement

\begin{tabular}{|c|c|c|c|c|c|}
\hline \multicolumn{2}{|c|}{ Sports disciplines } & $\begin{array}{c}\text { Chest } \\
\text { perim. }\end{array}$ & $\begin{array}{c}\text { Perim. } \\
\text { respir. }\end{array}$ & $\begin{array}{c}\text { Perim. } \\
\text { expir. }\end{array}$ & $\begin{array}{c}\text { Chest } \\
\text { elasticity }\end{array}$ \\
\hline \multirow{2}{*}{ Volleyball } & Av. & 86.3 & 92.1 & 83.7 & 8.4 \\
\cline { 2 - 6 } & SD & \pm 3.9 & \pm 4.1 & \pm 3.9 & \pm 1.2 \\
\hline $\begin{array}{c}\text { Combat } \\
\text { sports }\end{array}$ & Av. & 95.6 & 100 & 91.2 & 8.8 \\
\cline { 2 - 6 } SD & \pm 10.2 & \pm 10.2 & \pm 9.9 & \pm 2.3 \\
\hline \multirow{2}{*}{ Gymnastic } & Av. & 89.3 & 92.3 & 85.8 & 6.5 \\
\cline { 2 - 6 } & SD & \pm 10.2 & \pm 11.4 & \pm 9.3 & \pm 2.6 \\
\hline \multirow{2}{*}{ Basketball } & Av. & 88.5 & 94.5 & 86.3 & 8.2 \\
\cline { 2 - 6 } & SD & \pm 4.2 & \pm 3.6 & \pm 4.1 & \pm 1.8 \\
\hline \multirow{2}{*}{ Soccer } & Av. & 88.7 & 94.4 & 86.2 & 8.2 \\
\cline { 2 - 6 } & SD & \pm 6.0 & \pm 5.8 & \pm 6.1 & \pm 3.1 \\
\hline
\end{tabular}

Table 5: Reserve function components breath exchanger

\begin{tabular}{|c|c|c|c|}
\hline \multicolumn{2}{|l|}{ Sports disciplines } & $\begin{array}{c}\text { Perimeters } \\
\text { difference breathig } \\
\text { and tranquility }\end{array}$ & $\begin{array}{c}\text { Perimeters } \\
\text { difference } \\
\text { tranquility and } \\
\text { breathig }\end{array}$ \\
\hline Volleyball & Av. & 5.8 & 2.6 \\
\hline Combat sports & Av. & 4.4 & 4.5 \\
\hline Soccer & Av. & 2.8 & 3.7 \\
\hline Gymnastic & Av. & 6.0 & 2.2 \\
\hline Basketball & Av. & 5.7 & 2.5 \\
\hline
\end{tabular}

In table 6, presented spirometry, spiro. 1, spiro. 2 and vital capacity. Data show that greater spirometry have volleyball, while the largest vital capacity have basketball [15].

Table 6: Present spirometry, spiro. 1, spiro. 2 and vital capacity

\begin{tabular}{|c|c|c|c|c|c|}
\hline \multicolumn{2}{|c|}{ Sports disciplines } & Spirom. & Spiro. 1 & Spiro. 2 & Vital kapacity \\
\hline \multirow{2}{*}{ Volleyball } & Av. & 4710 & 24.7 & 65 & 4133 \\
\hline & SD & \pm 674.0 & \pm 3.2 & \pm 6.8 & \pm 276.6 \\
\hline \multirow{2}{*}{$\begin{array}{c}\text { Combat } \\
\text { sports }\end{array}$} & Av. & 4044.7 & 21.6 & 50.4 & 4158.4 \\
\hline & SD & \pm 647.0 & \pm 3.3 & \pm 9.0 & \pm 573.1 \\
\hline \multirow{2}{*}{ Gymnastic } & Av. & 4016.7 & 21.4 & 53.6 & 4110.3 \\
\hline & SD & \pm 962.6 & \pm 4.6 & \pm 7.3 & \pm 746.1 \\
\hline \multirow{2}{*}{ Basketball } & Av. & 4675 & 22.6 & 56.6 & 4317.2 \\
\hline & SD & \pm 668.0 & \pm 3.6 & \pm 9.1 & \pm 234.8 \\
\hline \multirow{2}{*}{ Soccer } & Av. & 4380 & 23.3 & 57.7 & 4230.9 \\
\hline & SD & \pm 719.9 & \pm 4.1 & \pm 11.8 & \pm 379.6 \\
\hline
\end{tabular}

\subsection{Female}

In table 7 , presented data anthropometric parameters of female subjects. From the data indicates that age is almost the same. Height, bust and weight vary according to the type of sport [17].

Table 7: Data of sportswomen anthropometric measurements

\begin{tabular}{|c|c|c|c|c|c|}
\hline \multicolumn{2}{|c|}{ Sports disciplines } & Age & Height & Bust & Weight \\
\hline \multirow{2}{*}{$\begin{array}{c}\text { Volleyball } \\
\text { Combat } \\
\text { sports }\end{array}$} & Av. & 17.8 & 165.6 & 86.3 & 54.4 \\
\cline { 2 - 6 } & Av. & \pm 3.9 & \pm 6.0 & \pm 3.1 & \pm 8.1 \\
\cline { 2 - 6 } Gymnastic & \pm 0.9 & 157.6 & 83.9 & 52.3 \\
\cline { 2 - 6 } & Av. & 16.4 & 154.3 & 81.1 & 52.2 \\
\hline \multirow{2}{*}{ Basketball } & \pm 1.46 & \pm 5.1 & \pm 2.7 & \pm 6.7 \\
\cline { 2 - 6 } & Av. & 17.8 & 169.82 & 88.86 & 60.3 \\
\hline \multirow{2}{*}{ Athletic } & SD & \pm 3.4 & \pm 3.6 & \pm 3.1 & \pm 3.6 \\
\cline { 2 - 6 } & SD & 17.27 & 160.5 & 85.2 & 54.45 \\
\hline
\end{tabular}

In table 8 , presented three perimeters of chest, with whom have tried to present, an indication static, it is the perimeter of the chest at rest or respiratory normal and two chest perimeter, which are perimeter in respiration deeper of the expiration deeper perimeter. Both perimeters calculate the difference between them, which gives us the elasticity of chest or breath exchanger muscle strength [16].

Table 8: Female chest perimeter measurement

\begin{tabular}{|c|c|c|c|c|c|}
\hline \multicolumn{2}{|c|}{ Sports disciplines } & $\begin{array}{c}\text { Chest } \\
\text { perim. }\end{array}$ & $\begin{array}{c}\text { Perim. } \\
\text { respir. }\end{array}$ & $\begin{array}{c}\text { Perim. } \\
\text { expirat. }\end{array}$ & $\begin{array}{c}\text { Chest } \\
\text { elasticity }\end{array}$ \\
\hline \multirow{2}{*}{ Volleyball } & Av. & 83.9 & 88.4 & 80.3 & 8.1 \\
\cline { 2 - 6 } & SD & \pm 6.0 & \pm 5.3 & \pm 5.3 & \pm 2.3 \\
\hline $\begin{array}{c}\text { Combat } \\
\text { sports }\end{array}$ & Av. & 82.2 & 85.8 & 79.4 & 6.4 \\
\cline { 2 - 6 } GD & \pm 4.0 & \pm 3.7 & \pm 3.2 & \pm 1.5 \\
\hline \multirow{2}{*}{ Gymnastic } & Av. & 81.4 & 85.6 & 76.8 & 8.8 \\
\cline { 2 - 6 } & SD & \pm 4.5 & \pm 4.6 & \pm 3.5 & \pm 2.55 \\
\hline \multirow{2}{*}{ Athletic } & Av. & 86.32 & 92.64 & 83 & 9.64 \\
\cline { 2 - 6 } & SD & \pm 4.0 & \pm 4.3 & \pm 2.5 & \pm 2.7 \\
\cline { 2 - 6 } & Av. & 84.4 & 88.9 & 80.3 & 8.6 \\
\hline
\end{tabular}

Table 9 perimeters differences presented almost the same appearance. Athletics is different from other sports, having a smaller difference between the two respiratory acts [18].

\section{Volume 5 Issue 7, July 2016 www.ijsr.net}




\section{International Journal of Science and Research (IJSR) \\ ISSN (Online): 2319-7064}

Index Copernicus Value (2013): 6.14 | Impact Factor (2015): 6.391

Table 9: Reserve function components breath exchanger

\begin{tabular}{|c|c|c|c|}
\hline \multicolumn{2}{|l|}{ Sports disciplines } & $\begin{array}{c}\text { Perimeters } \\
\text { difference } \\
\text { breathig and } \\
\text { tranquility }\end{array}$ & $\begin{array}{c}\text { Perimeters } \\
\text { difference } \\
\text { tranquility } \\
\text { and breathig }\end{array}$ \\
\hline Volleyball & Av. & 4.5 & 3.6 \\
\hline Combat sports & Av. & 3.6 & 2.8 \\
\hline Athletic & Av. & 4.6 & 4.1 \\
\hline Gymnastic & Av. & 4.3 & 3.6 \\
\hline Basketball & Av. & 6.3 & 3.3 \\
\hline
\end{tabular}

In Table 10 are presented spirometry, spiro. 1 and 2 as well as vital capacity. The latter is calculated on the basis of body size, so the need for oxygen, which is the body of this size data, which means the size of the organ that suck oxygen from the environment. In this way, we can compare the current state of the subject (spirometry) and its predictable indicator (vital capacity). Also, the two indicators relative are shown, whom are reports spirometry, height and body weight [15].

Table 10: Present spirometry, spiro. 1, spiro. 2 and vital capacity

\begin{tabular}{|c|c|c|c|c|c|}
\hline \multicolumn{2}{|c|}{ Sports disciplines } & Spirom. & Spiro. 1 & Spiro. 2 & Vital kapacity \\
\hline \multirow{2}{*}{$\begin{array}{c}\text { Volleyball } \\
\text { Combat } \\
\text { sports }\end{array}$} & SD & \pm 3235.7 & 18.1 & 55.5 & 3038.4 \\
\cline { 2 - 6 } & Av. & 2720.0 & \pm 2.0 & \pm 7.9 & \pm 174.3 \\
\hline \multirow{2}{*}{ Gymnastic } & \pm 228.0 & \pm 1.1 & \pm 3.7 & \pm 126.1 \\
\cline { 2 - 6 } & Av. & 3062.5 & 17.7 & 52.6 & 3027.0 \\
\hline \multirow{2}{*}{ Basketball } & SD. & 2737.5 & 16.4 & 50.1 & 2844.3 \\
\cline { 2 - 6 } & SD & \pm 238.7 & \pm 1.3 & \pm 8.5 & \pm 89.1 \\
\hline \multirow{2}{*}{ Athletic } & Av. & 3463.6 & 18.97 & 53.35 & 3186.1 \\
\cline { 2 - 6 } & SD & \pm 304.2 & \pm 1.70 & \pm 5.63 & \pm 168.0 \\
\hline
\end{tabular}

\section{Discussion}

\subsection{Male}

In this study tried to create a connection between static and dynamic anthropometric indicators, parameters pulmonary and their connections, as prerequisites development functional of organic. Among the anthropometric indicators, in addition to height and weight, to us served in the calculation of metabolism or basic energy needs and later the level of theoretical vital capacity. Measured and anthropometric indicators, directly related to the activity of pulmonary function, such as the chest perimeter in serenity and two perimeters his deep respiration and expiration. As shown in figure 1, all three perimeters have a walking parallel to one another, where higher levels are combat sports.

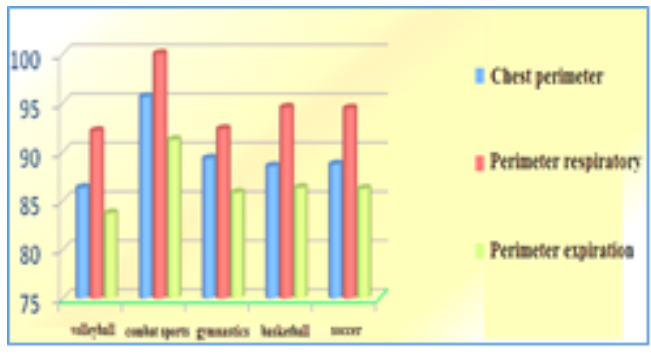

Figure 1: Data perimeter of chest males
In addition to measuring perimeters, calculated the difference between the perimeters of deep respiration and expiration, pointing to a very important functional parameter of thoracic cage, which is the elasticity of chest. In figure 2, it is shown this parameter, which is the highest of combat sports and lower the gymnasts.

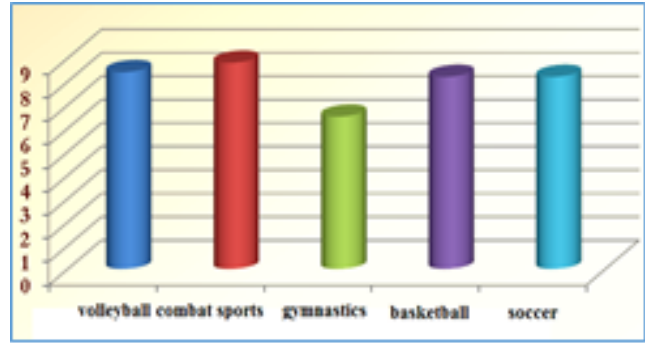

Figure 2: Level elasticity chest males

In figure 3, the report is submitted, perimeter respiration tranquility, and the second report presented by the dark color that is the parameters of tranquility - respiration. We see that in these two reports, it appears that the first report is of greater value than the second report. So, we can say that the act of respiration, we know theoretically, is the most important that asset and in breath exchanger. It should be noted in respiratory gymnastics, which is used in many sports and rehabilitation of injured or sick.

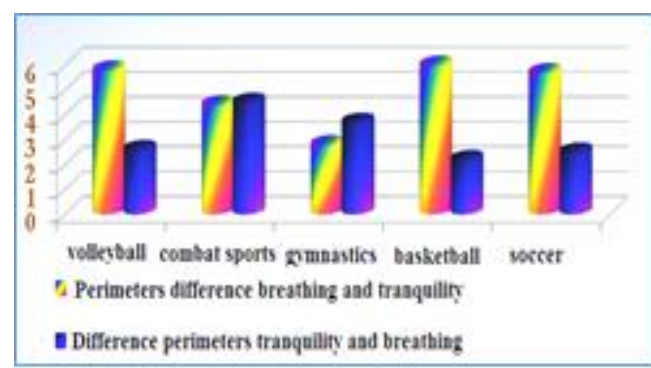

Figure 3: Changes in perimeter between respiration and expiration males

Figures 4 and 5, are presented as real respiratory function, are measurements spirometry and vital capacity, faced with the parameter estimates by energy should needs, have a sportsman with a weight, height and age specific. Vital capacity calculate presented, seeing rates tables usually take for reference only height, avoiding age and weight.

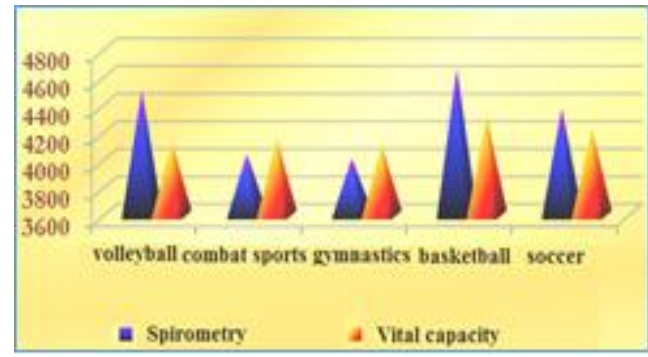

Figure 4: Data on the level of spirometry and vital capacity males

This comparison has come up that sportsmen generally have a spirometry higher than the minimum rates calculated, in addition to combat sports, to which turns out a pronounced overweight. Therefore, vital capacity appears higher than

Volume 5 Issue 7, July 2016 www.ijsr.net 


\section{International Journal of Science and Research (IJSR) \\ ISSN (Online): 2319-7064}

Index Copernicus Value (2013): 6.14 | Impact Factor (2015): 6.391

spirometry measurements.

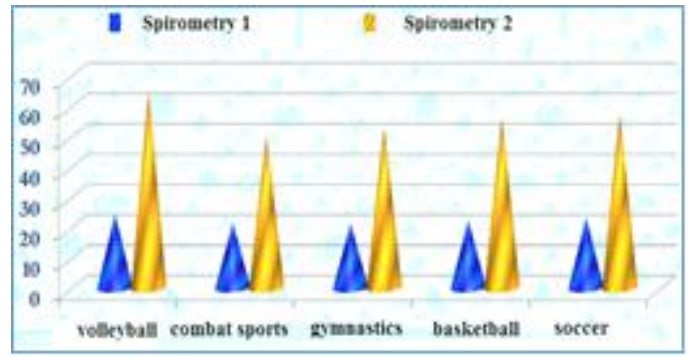

Figure 5: Level spirometry 1 and 2, according sports males

\subsection{Female}

Women, anthropometric dimensions are lower than men. Combat sports as males, presented with low levels of perimeters, along with gymnastics. The three perimeters as shown in figure 6 give such a ranking, where it seems that basketball is presented first in the three perimeters measured, followed by athletics and volleyball, then the last two gymnastics and combat sports. Should note that the perimeters of tranquility and respiration, as high are the better it is, while the perimeter of expiration is lower, the better it is. Also in this last combat sports have a negative presentation, having a perimeter expiration level almost at the same level with volleyball and athletics.

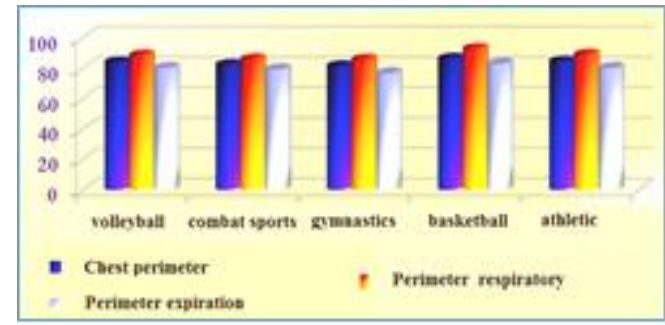

Figure 6: Data perimeter of chest females

In figure 7 is shown elasticity chest again see the same phenomenon happening, that we saw in the previous graph, where combat sports are stronger elasticity than other sports. Ranking continues to be the same as shown above indicators, ranging from basketball, athletics, volleyball and gymnastics.

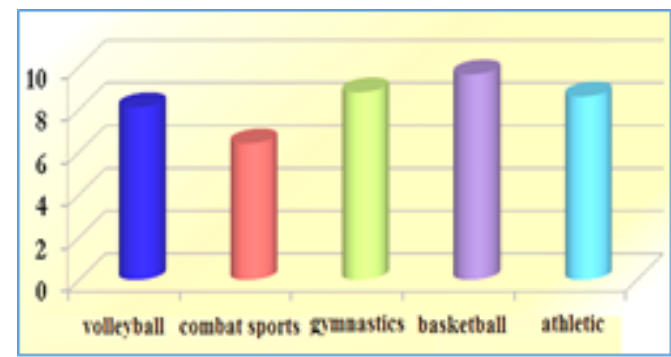

Figure 7: Level elasticity chest females

Figure 8 shows the correlation between the two actions breath exchanger, it is respiration and exhaling. According to the figures, it turns out again that basketball is at the highest levels in two acts breath exchanger taken together. But notice that these ingredients contribute in different ways to this level, basketball players difference respiratory perimeter of tranquility and the perimeter to tranquility of expiration is great. Athletes the first difference is $10 \%$ higher than second.
The other sports, it is about $20-30 \%$ higher.

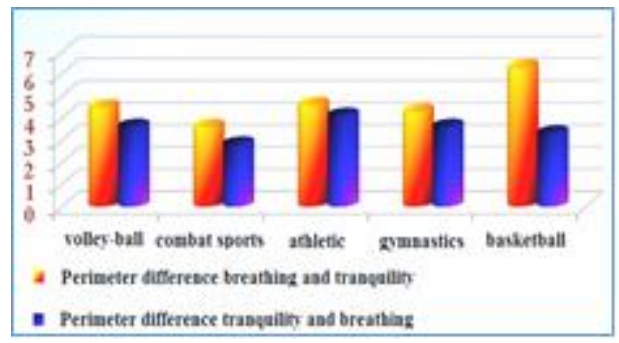

Figure 8: Changes in perimeter between respiration and expiration females

In figure 9, have reflected the alveoli indicator measure, which we called spirometry and the indicator is calculated (vital capacity), requests that the individual should have the weight, height, age assigned by gender. So, this indicator is calculated based on the theoretical metabolic basal. We see that in sports volleyball and basketball, have a positive margin for spirometry, which indicates that these sports give a good development apparatus breath exchanger. While other sports are the norm, given that the two parameters are almost the norm.

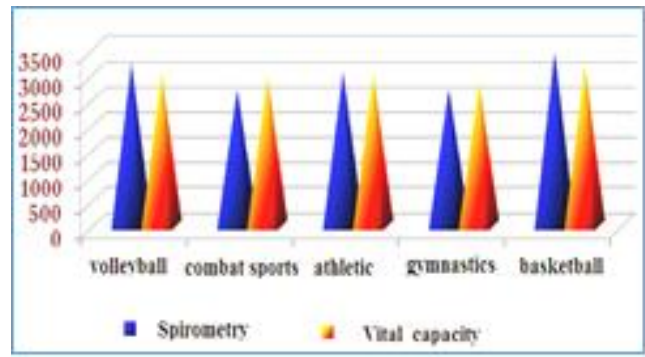

Figure 9: Data on the level of spirometry and vital capacity females

In figure 10 , it is shown relative spirometry in relation to body weight to height. As we see, the ratio of body weight, spirometry, presented slightly higher in the sports of volleyball and basketball at the lowest combat sports, to report to the height, the difference between sports is not fairly visible. By this reasoning, it appears that relative difference makes weight is a variable quite unsteady.

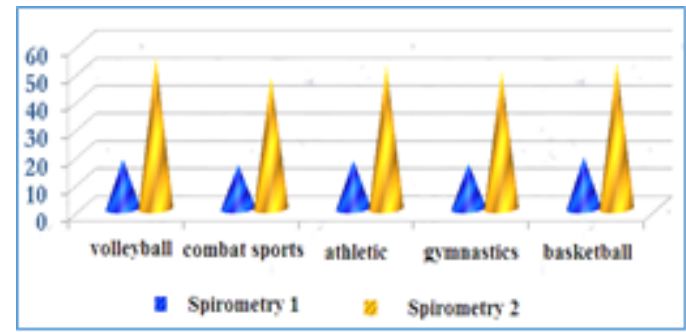

Figure 10: Level spirometry 1 and 2, according sports females

A special importance, the size of the respiratory parameters, have and magnitude body, especially body height. As shown in figure 11 , spirometry or vital capacity has a correlation in the right proportion to body height, which is the correlation coefficient $\mathrm{R}=0.78$ [19]. 


\section{International Journal of Science and Research (IJSR) \\ ISSN (Online): 2319-7064}

Index Copernicus Value (2013): 6.14 | Impact Factor (2015): 6.391

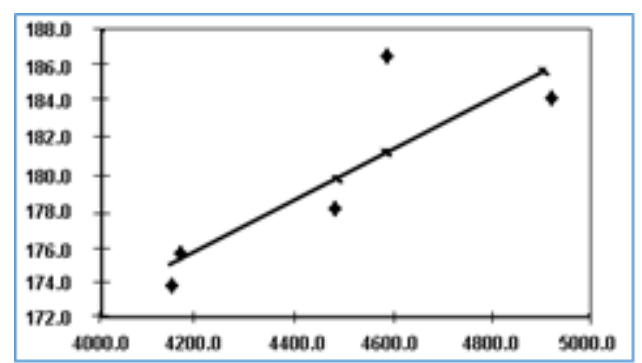

Figure 11: Connection between spirometry and body height

As with body height, we have also the same proportion with the perimeter of the chest, where the correlation coefficient is $\mathrm{R}=0.94$ [19].

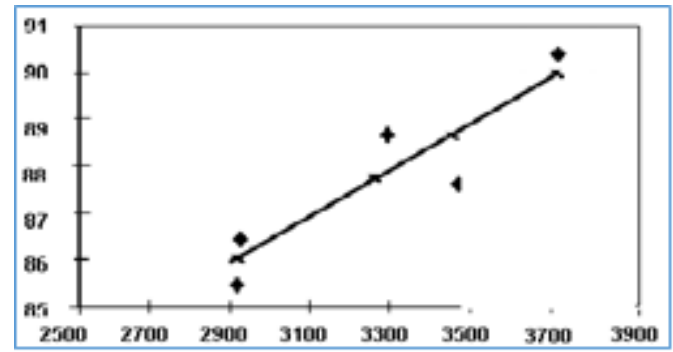

Figure 12: Report vital capacity with chest perimeter [19]

As we see, of all the data extracted from the measurements, introduces a combination of many factors that affect directly and indirectly in pulmonary parameters. Changes in general, to all sports, for males and females, are positive, which indicates that physical activity positively affects the breath exchanger apparatus. This is seen clearly in confrontation between the measured vital capacity and vital capacity calculated or theoretical (see figures 4-10), where the measured parameters are always higher. This indicates that the apparatus body fulfill and exceeds the needs of tranquility as well as during physical strain. From these conclusions exception static sports, as weightlifting, wrestling, boxing (combat sports), where sportsmen are characterized by an overweight, which causes an increased energy requirements, thus increasing the capacity theoretical vital.

Figures 11 and 12, indicates that these parameters have a very close relationship with body size, especially circumference of the chest, which is the main condition, which determines the size of the thoracic cage (box holder of the lungs). Pulmonary parameters, in this case the increase in vital capacity, positively affects increasing of the maximum oxygen consumption. So indicates that affect lung volumes as a prerequisite to increasing the general physical preparation or sustainability, the main indicator as VO2max. This important aspect of the level of preparation of different sports [19].

Black LF, \& Hyatt RE submitted interconnections between vital capacity and maximum volume respirator. This correlation shows that, apart from influence on maximum oxygen consumption, the lungs have another function, which is the acid-base balance. How much more powerful to be breathing, the sooner placed this balance. This combination to present, among them bodily and pulmonary parameters, the result of those functional (VO2max, acid-basic balance), shows the importance of these tests, which must be construed together and not separately [20].

Subjects that have measured included in the normality of the population, but there are cases when elite sportsmen have changes in body size, as is the size of the thorax. One such case is the italian cyclist Fausto Copi, who average body size $176 \mathrm{~cm}$. high, had a vital capacity of $7000 \mathrm{ml}$. This was explained by the fact that he had a more exaggerated thoracic cage, dropping eye diameter his anterior-posterior consequently, had an enlarged thoracic circumference [21].

The chest perimeters have a special importance to the beginning of a sport (genetics), but in this case without excluding the importance of physical activity, is quite influential in respiratory muscle mechanics. High efficiency respiratory affects energy savings by respiratory muscle. It is known that about $10 \%$ of the total energy spent consuming respiratory muscles, but when their yields rise, the percentage of low spending [22].

\section{Conclusions}

- Pulmonary parameters are not influenced only by physical activity, but also by anthropometric parameters.

- In breath exchanger activity, the most important role is played by the act of respiration than the expiration.

- Vital capacity measured in this group of subjects is higher than the theoretical vital capacity.

- Vital capacity, normalized to body weight and height, is almost equal in all sports.

- Because these sportsmen subjects have increased lung volumes, according to [19], they have premises and oxygen consumption up.

\section{References}

[1] MR. Becklake, "Gender Differences in Airway Behavior (Physiology) Over the Human Lifespan", pp.25, 8-12, 2003. (monograph style)

[2] S. Stanojevic, A. Wade, J. Hankinson, A. Coates, J. Stocks, T.J. Cole, "Continuous Reference Ranges for Spirometry”, pp. 176,606, 2007. (book style)

[3] M. P. Canaj, K. Hoxha, "Sports Physiology", SHBLU, pp. 63-66, 2004. (book style)

[4] X. Wang, DW. Dockery, D. Wypij, ME. Fay, Jr. Ferris, "Pulmonary Function Between 6 and 18 Years of Age", pp. 15, 75-88, 1993. (journal style)

[5] S. Chinn, D. Jarvis, C. Svanes, P. Burney, "Sources of Variation in Forced Inspiratory", Volume One and Forced Vital Capacity, pp.767-773, 2006.(book chapter style)

[6] RJ. Knudson, MD. Lebowitz, CJ. Holberg, B. Burrows, "Changes in the Normal Maximal Expiratory", pp. 127, 725-734, 1983. (book style)

[7] TJ. Overend, CM. Anderson, D. Lucy, “ The Effect of Incentive Spirometry”, pp. 71-77, 120, 2001. (journal style)

[8] JA. Thomas, JM. McIntosh,"AAre Incentive Spirometry Intermittent Positive Pressure Breathing and Deep Breathing Exercises", pp. 3-10, 74,1994. (book style) 


\section{International Journal of Science and Research (IJSR) \\ ISSN (Online): 2319-7064}

Index Copernicus Value (2013): 6.14 | Impact Factor (2015): 6.391

[9] M. Rosenthal, SH. Bain, D. Cramer, P Helms, D. Denison, A. Bush, JO. Warner, "Lung Function in Children Aged 4 to 19 Years", pp. 48,794-802, 1993. (article journal style)

[10] N. Ambrosino, R. Corsico, C. Fracchia, C. Rampulla, "Riabilitazione Respiratorie", UTET Torino, pp. 99103, 1996. (technical report style)

[11] S. Stanojevic, A. Wade, TJ. Cole, J. Stocks, "Population Specific Reference Equations", pp. 29, 115, 2007. (journal style)

[12] PH. Quanjer, GJ. Borsboom, B. Brunekreff, M. Zach, G. Forche, JE. Cotes, J. Sanchis, P. Paoletti, "Spirometry Reference Values for European Children and Adolescents", Revisited Pediatric Pulmonary, pp. 19, 135-142,1995. (journal style)

[13] J. A. Harris, F. G. Benedict, "Proceedings of the National Academy of Sciences". Vol. 4, No. 12, pp. 370-373,1918. (technical report style)

[14] J. A. Harris, F. G. Benedict, Washington, DC, Carnegie Institution, 1919. (technical report style)

[15] P. Subbarao, P. Lebecque, M. Corey, AL. Coates, "Comparison of Spirometric Reference Values", pp. 37, 515-522, 2004. (book style)

[16] K. Özer, "Anthropometry, Planning Morphology in Sports”, Kazanc1, Istanbul, pp. 47- 86, 1993. (journal style)

[17] T.G.Lohman,A. F.Roche, R. Martorel, "Anthropometric Standards Reference Manuel, pp. 111, 1988. (technical report style)

[18] P. Lebecque, K. Desmond, Y. Swartebroeckx, P. Dubois, J. Lulling, A. Coate, "Measurement of Respiratory System Resistance by Forced Oscillation in Normal Children”, pp. 10,117-122,1991. (journal style)

[19] P Astrand,"Human Physical Fitness with Special Reference to Sex and Age", Physiol. Rev. Jul,36,(3),pp.327-335,1956. (bulletin style)

[20] LF. Black, RE. Hyatt, "Maximal Pespiratory Pressures Normal Values and Relationship to Age and Sex", Am. Rev. Respir. Dis., pp. 696-702,1969. (bulletin style)

[21] P. Cerretelli, G. Brandi, I. Brambilla, "Il Massino Lavoro Potenziale dell'Apparatus Respiratocio come Phoro di Funzionaleta nei Hogazzi", Minerva Medica;pp. 50,499-501,1959. (book style)

[22] A. Bellone, Riabilitazione Respiratoria, Nuovi Orientamenti, Media, Trieste,pp. 168-170,1997. (journal style)

\section{Author Profile}

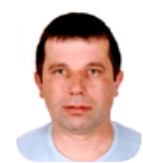

Edison Ikonomi 1987 graduated at the Institute of Physical Culture "Vojo Kushi" gymnastic specialty Tirana. During 2009 graduated M.S in physical education and sports, physical education specialty didactic. Physical education teacher in Berat city schools from 1988 to 2001. Movement Sciences Faculty lecturer, Department of Sports University sports science Tirana rank of Doc. Phd since 2001. Gymnast and coach of the national team in twenty years, with participation in high level international events. Specializing in the field in artistic gymnastics in different European countries.

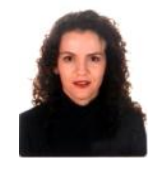

Eglantina Daulle during 1999 graduated in Tirana University, Faculty of Philology and Department of Geography. During 1999-2006 teacher history and athletic trainer at Berat city. She graduated in 2007 University of Tirana M.S Finance - Banking. Since 2006 International payments ABI BANK Tirana, as well as athletic trainer youngest female sports club Partizani Tirana.

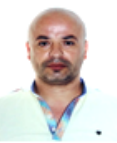

Edmont Çerra during 2006 degree Academy Physical Education and Sport "Vojo Kushi" Tirana. During 2009 graduates M.S in " research in high schools ".Since 2010 works in the Ministry of Environment and men's artistic gymnastics coach young male sporting club Partizani Tirana.

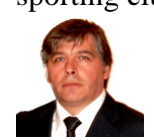

Ferdinand Canaj during in 1989 graduated teacher of physical education, Tirana. During 1996 M.S "Didact of physical education".2002 degree Phd. During 2012 degree UBIS Geneve. Advanced Studies in media \& communication. During 2012 graduate diploma ISSAT Tirana M.S. During 2016 Ass.Prof.Phd. During 2000-2016 academic staff at Academy Sports Physical Education "Vojo Kushi" today University Sports Tirana. 